\title{
ANALISIS SPEKTRAL DALAM PENENTUAN PERIODISITAS SIKLUS CURAH HUJAN DI WILAYAH SELATAN JATILUHUR, KABUPATEN SUBANG, JAWA BARAT
}

\author{
Spektral Analysis of Periodicity Rainfall Cycle in Southern Part of Jatiluhur, Subang District, West Jawa \\ Dyah Susilokarti ${ }^{1}$, Sigit Supadmo Arif ${ }^{2}$, Sahid Susanto², Lilik Sutiarso² \\ ${ }^{1}$ Direktorat Jenderal Prasarana dan Sarana Pertanian, Kementrian Pertanian, \\ Jl. R.M. Harsono No. 3 Ragunan, Pasar Minggu, Jakarta Selatan 12550 \\ ${ }^{2}$ Jurusan Teknik Pertanian, Fakultas Teknologi Pertanian, Universitas Gadjah Mada, \\ Jl. Flora No. 1, Bulaksumur, Yogyakarta 55281 \\ Email :dysuka_0668@yahoo.com
}

\begin{abstract}
ABSTRAK
Data curah hujan dipelajari salah satunya untuk mengetahui bagaimana curah hujan di suatu wilayah mempunyai rentang waktu untuk membentuk suatu pola berulang. Siklus merupakan suatu perubahan atau gelombang naik dan turun dalam suatu periode serta berulang pada periode lain. Siklus mempunyai frekuensi yang dapat diselesaikan dalam 1 periode waktu. Transformasi Fourier merupakan algoritma untuk mengubah domain waktu X menjadi domain atau spectrum frekuensi Y, dengan cara menguraikan sinyal menjadi komponen sinusoidal. Penelitian ini menggunakan metode Fast Fourier Transform (FFT) untuk mencari sifat berulangnya trend curah hujan di wilayah selatan Jatiluhur Kabupaten Subang. Simulasi model menggunakan data curah hujan bulanan tahun 1975 - 2012. Hasilnya menunjukkan trend curah hujan di lokasi penelitian berulang setiap 12 bulan sekali (1 siklus). Prediksi curah hujan dilakukan dengan menggunakan data curah hujan 5 tahun dan menggunakan observasi data 5 tahun berikutnya sebagai pembanding hasil prediksi untuk melihat performa yang dihasilkan. Performa hasil prediksi menggunakan Mean Square Error (MSE) sebagai standar perhitungan derivasi perbedaaan antara data real dan data pemodelan. Hasil analisis pada saat validasi model didapatkan MSE = 14,92 dengan tingkat kepercayaan 95\%. Dengan menggunakan analisis FFT untuk menghitung nilai error (perbedaan antara nilai perhitungan model ANN dengan data sebenarnya), diperoleh perubahan siklus curah hujan terjadi dalam kurun waktu 71,68 bulan atau sekitar 5-6 tahun.
\end{abstract}

Kata kunci: Curah hujan, prediksi, Fast Fourier Transform (FFT), Mean Square Error (MSE), Kabupaten Subang

\begin{abstract}
Rainfall data was studied to know how rainfall in the region has a span of time to form a repetitive pattern. The cycle is a change or a wave up and down within a period and repeated at other periods. The cycle has a frequency that can be completed in one period of time. Fourier transform is an algorithm to convert the time domain $\mathrm{X}$ to the domain or the frequency spectrum $\mathrm{Y}$, by breaking the signal into a sinusoidal component. This study used the Fast Fourier Transform (FFT) to find the nature of the trend recurrence of rainfall in the southern region of Jatiluhur Subang. Simulation model was done using monthly rainfall data 1975 - 2012. The results showed a trend of rainfall in the study area was repeated every 12 months ( 1 cycle). Rainfall prediction was done by using a 5 -year rainfall data and used the data observation of the next 5 years as a comparison result predicted to see the performance. Performance prediction was resulted using the Mean Square Error (MSE) used to obtain the difference between the standard derivation calculation of observed data and data modeling. The results of the analysis at the time of validation of the model was MSE $=14.92$ with a $95 \%$ confidence level. FFT used to calculate the value of the error (the difference between the values calculated by the ANN model and observed data) resulted in the change cycle of rainfall occurs over a period of months or approximately 71.68 months or 5-6 years.
\end{abstract}

Keywords: Rainfall, prediction, Fast Fourier Transform (FFT), Mean Square Error (MSE), Subang District 


\section{PENDAHULUAN}

Perubahan iklim telah mempengaruhi pola curah hujan yang berdampak terhadap sistem budidaya tanaman padi di wilayah selatan Jatiluhur, yang mana wilayah ini untuk pemenuhan kebutuhan irigasi hanya mengandalkan air dari sumber air setempat, sehingga keberhasilan atau kegagalan panen di lokasi ini sangat tergantung pada ketersediaan air seperti sungai, mata air dan curah hujan. Langkah awal pada perencanaan budidaya tanaman padi di wilayah ini adalah memastikan ketersediaan air irigasi sesuai tahap pertumbuhan tanaman. Untuk itu diperlukan pengetahuan dan informasi tentang pola curah hujan dan siklus perubahan iklim di wilayah ini.

Variabilitas curah hujan di Indonesia sangat kompleks dan merupakan bagian chaotic dari variabilitas Monsun (Ferranti, 1997 dalam Aldrian dan Susanto, 2003). Secara umum curah hujan di wilayah Indonesia di dominasi oleh adanya pengaruh beberapa fenomena, Monsun dan pergerakan ITCZ (Intertropical Convergence Zone) (Aldrian dan Susanto, 2003), system Monsun Asia-Australia, El Nino, sirkulasi Timur-Barat (Walker Circulation) dan sirkulasi Utara-Selatan (Hadley Circulation), serta beberapa sirkulasi karena pengaruh lokal (McBride, 2002).

Iklim di Indonesia pada umumnya dipengaruhi oleh fenomena-fenomena yang memiliki periode berulangnya seperti Zona Konvergensi Inter Tropis/Inter Tropical Convergence Zone (ITCZ) yang memiliki periode berulang 6 bulan, angin monsun yang memiliki periode berulang 12 bulan (Hermawan, 2010), Osilasi Madden Julian yang memiliki periode berulang 2 hingga 3 bulan (Anonymous, 2013), serta osilasi dua tahunan/Quasi Biennial Oscillation (QBO) yang memiliki periode berulang 20 hingga 32 bulan (Sathiyamurthy dan Mohanakumar, 2002)

Metode Fast Fourier Transform (FFT) merupakan metode untuk mengetahui periodisitas sebuah data yang berulang kembali. Periodogram yang dihasilkan berupa grafik yang menunjukkan nilai kekuatan kerapatan spektral dengan variabel periode signal. Kekuatan Kerapatan Spektral (KKS) merupakan nilai kekuatan (daya) sebuah signal dapat berulang kembali pada variabel frekuensi atau periode. Periode signal hujan menunjukkan waktu yang diperlukan untuk terjadinya satu siklus signal data hujan. Periodogram akan menghasilkan periode dengan kekuatan kerapatan spektral tertinggi (Sagita dkk., 2013).

Analisis spektral adalah analisis runtun waktu yang dapat menguraikan data ke dalam himpunan gelombang sinus dan atau kosinus pada berbagai frekuensi yang dapat digunakan untuk mencari periodisitas tersembunyi.

Tujuan dari penulisan makalah ini adalah menentukan periodisitas tersembunyi pada data curah hujan di wilayah selatan Jatiluhur Kabupaten Subang menggunakan metode Fast Fourier Transform (FFT).

\section{METODE PENELITIAN}

\section{Lokasi Studi}

Lokasi studi adalah beberapa Daerah Irigasi (DI) di wilayah selatan Jatiluhur Kabupaten Subang yaitu DI. Curugagung, DI. Cileuleuy, DI. Leuwinangka, dan DI. Pangsor. Lokasi ini dipilih karena wilayah ini untuk memenuhi kebutuhan air irigasi hanya bergantung pada sumber setempat berupa mata air, sungai dan hujan. Irigasi di wilayah ini tidak mendapat suplesi dari waduk Jatiluhur, sehingga dampak perubahan iklim di wilayah ini dapat dibuktikan pada ketersediaan air irigasinya.

Dampak perubahan iklim terhadap naiknya permukaan air laut mengakibatkan instrusi air laut di sebagian lahan sawah di sepanjang pantai utara Jawa. Intrusi air laut mengakibatkan degradasi lahan pertanian seperti erosi, sedimentasi, tanah longsor, bencana banjir dan hilangnya lahan sawah, serta penurunan produktivitas lahan akibat salinitas. Pada penelitian sebelumnya diketahui bahwa kabupaten Subang yang merupakan sentra produksi pangan di Jawa Barat mengalami penurunan produksi beras sekitar 300.000 ton akibat intrusi air laut (Boer dkk. 2009). Selain itu, Kabupaten Subang yang berada di kawasan pesisir Pantai Utara Jawa juga rentan terhadap dampak perubahan iklim lainnya seperti kekeringan, dan serangan hama penyakit tanaman. Bencana tersebut menyebabkan penurunan produksi pertanian dan ke gagalan panen. Serangan hama penyakit utama tanaman padi adalah tikus dengan luas serangan (124.000 ha/th), penggerek batang $(80.127 \mathrm{ha} / \mathrm{th})$ wereng coklat $(28.222 \mathrm{ha} /$ th), penyakit tungro $(12.078 \mathrm{ha} / \mathrm{th})$ dan blas $(9.778 \mathrm{ha} / \mathrm{th})$ dengan kehilangan hasil mencapai 212.948 ton GKP/musim tanam dan pada saat anomali iklim serangan hama tersebut cenderung makin luas (Soetarto dkk., 2001). Anomali iklim yang terjadi pada tahun 1997 yaitu El-Nino yang diikuti LaNina menguntungkan perkembangan wereng coklat. Wereng coklat biasanya menjadi masalah pada musim hujan, tetapi pada waktu tersebut juga menyebabkan kerusakan (puso) pada tanaman padi gogo di Subang (Irsal Las dkk., 20072010).

\section{Data dan Perangkat Lunak}

a. Penelitian ini menggunakan data curah hujan wilayah bulanan priode tahun 1975 - 2012. Data diperoleh dari 10 stasiun curah hujan di sekitar lokasi penelitian yang terdiri dari : (1) stasiun Kalijati; (2) stasiun Kasomalang, (3) stasiun Curugagung; (4) stasiun Cinangling; (5) stasiun Dangdeur; (6) stasiun Pegaden, (7) stasiun 
Ponggang, (8) stasiun Cindanglaya, (9) stasiun Ciseuti, dan (10) stasiun Subang.

b. Data diperoleh dari Lanud Suryadharma Kalijati Kabupaten Subang dan Divisi III Perum Jasatirta II Kabupaten Subang.

c. Alat yang digunakan dalam penelitian ini adalah seperangkat komputer dengan software MATLAB versi 2010a, Arc Gis 10.2, Microsoft excel dan Microsoft word 2007.

\section{Analisis Karakteristik Curah Hujan Wilayah}

Curah hujan yang menunjukkan besarnya Curah hujan yang terjadi di suatu daerah disebut curah hujan wilayah. Perhitungan curah hujan wilayah dari pengamatan curah hujan di beberapa titik. Salah satu cara analisis karakteristik curah hujan wilayah adalah dengan menggunakan metode Isohyet. Peta Isohyet digambarkan pada peta topografi berdasarkan data curah hujan (interval 10 - $20 \mathrm{~mm}$ ) pada titik pengamatan di dalam dan sekitar daerah yang dimaksud. Luas bagian daerah antara dua garis isohyet yang berdekatan diukur dengan planimeter. Harga rata-rata dari garis-garis isohyet yang berdekatan yang termasuk bagian-bagian daerah itu dapat dihitung. Curah hujan daerah dihitung menurut persamaan seperti dibawah ini.

$$
R=\frac{A_{1}+R_{1}+A_{2}+R_{2}+\ldots+A_{\mathrm{n}} R_{\mathrm{n}}}{A_{1}+A_{2}+\ldots+A_{n}}
$$

Keterangan :

$\mathrm{R}=$ Curah hujan rerata tahunan

$\mathrm{A}_{1}, \mathrm{~A}_{2}=$ Luas bagian antar dua garis isohyet

$\mathrm{R}_{1}, \mathrm{R}_{2}, \mathrm{R}_{\mathrm{n}}=$ Curah hujan rata - rata tahunan pada bagian $\mathrm{A}_{1}, \mathrm{~A}_{2}, \ldots, \mathrm{A}_{\mathrm{n}}$

Cara ini adalah cara rasoinal yang terbaik jika garis garis isohyet dapat digambarkan dengan teliti. Peta Isohyet dibuat menggunakan software ArcGis 10.2 dan hasilnya dapat dilihat pada Gambar 1, di bawah ini:

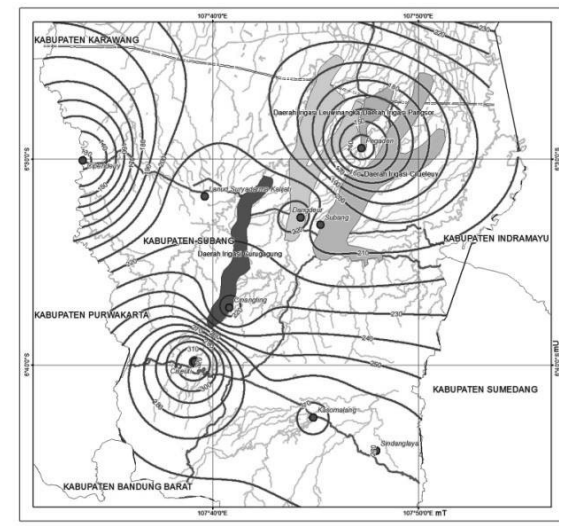

Gambar 1. Peta Isohyet

\section{Analisis Spektral}

Kajian periodesitas data perlu dilakukan untuk menambah informasi mengenai karakteristik dari data deret waktu, dan harus dilakukan pada kawasan frekuensi melalui analisis spektral (Mulyana 2004). Analisis spektral atau Power Spektral Density (PSD) merupakan suatu metode yang digunakan untuk mengestimasi fungsi densitas spectrum dari sebuah data runtun waktu. Analisis spektral membahas mengenai cara menelaah periodesitas data tersembunyi (hidden periodecities) yang sulit diperoleh pada saat kajian dilakukan pada kawasan (domain) waktu. Analisis spektral yang digunakan yaitu teknik Fast Fourier Transform (FFT). Data deret waktu dapat dinyatakan sebagai deret fourier yang merupakan fungsi harmonis, sehingga dengan membangun fungsi spektrum kuasanya, periodesitas data dapat ditentukan. Tetapi menentukannya tidak dapat dalam kawasan (domain) waktu, dan harus dalam kawasan frekuensi sebab fungsi spektrum kuasa merupakan fungsi atas autokorelasi dengan frekuensi. Metode ini menerapkan model yang sinusoidal, sehingga akan menghasilkan nilai prediksi yang sama untuk setiap waktu $(t)$ pada periode kapan pun.

Prinsip dasar dari metode dekomposisi deret waktu adalah mendekomposisi (memecah) data deret waktu menjadi beberapa pola dan mengidentifikasi masingmasing komponen dari deret waktu tersebut secara terpisah. Pemisahan ini dilakukan untuk membantu meningkatkan ketepatan peramalan dan membantu pemahaman atas perilaku deret data secara lebih baik (Makridakis dkk., 2003). Siklus merupakan suatu perubahan atau gelombang naik dan turun dalam suatu periode serta berulang pada periode lain. Siklus juga mempunyai frekuensi yaitu siklus yang dapat diselesaikan dalam 1 periode waktu. Indeks siklus diperoleh dari persamaan yang digunakan untuk perhitungan rata-rata bergerak dibagi dengan persamaan yang berfungsi untuk menghitung trend. Hal tersebut dilakukan jika modelnya multiplikatif, tetapi jika modelnya aditif maka indeks siklus diperoleh dari persamaan yang digunakan untuk perhitungan rata-rata bergerak yang dikurangi dengan persamaan yang berfungsi untuk menghitung trend.

Definisi deret fourier adalah sebagai berikut (Hermawan 2003):

$$
f(x)=a_{0}+\sum\left(a_{n} \cos \frac{2 n \pi t}{T}+b_{n} \sin \frac{2 n \pi x}{T}\right)
$$

dimana:

$a_{0}=\frac{1}{T} \int_{-T / 2}^{T / 2} f(t) d t$

$a_{n}=\frac{2}{T} \int_{-T / 2}^{T / 2} f(t) \operatorname{Cos} \frac{2 n \pi t}{T} d t$

$b_{n}=\frac{2}{T} \int_{-T / 2}^{T / 2} f(t) \operatorname{Sin} \frac{2 n \pi t}{T} d t$ 
Periodogram diaplikasikan pada suatu data curah hujan yang berbentuk data deret waktu. Data curah hujan bulanan tersebut digunakan sebagai masukan fungsi $(t)$ pada persamaan deret Fourier yang kemudian di transformasikan dalam fungsi frekuensi $(\omega)$. agar memperoleh persamaan Fast Fourier Transform (6)

$$
F(\omega)=\int_{-\infty}^{\infty} f(t) e^{-i \omega t} d t
$$

Nilai kekuatan kerapatan spektral pada peridogram diperoleh dari :

$$
K K S(\omega)=\frac{T}{2}\left(a_{p}^{2}+b_{p}^{2}\right)
$$

\section{Prediksi Curah Hujan}

Prediksi curah hujan dilakukan dengan menggunakan metode Artificial Neural Netwok (ANN) backpropagation. Model ANN backpropagation melatih jaringan untuk mendapatkan keseimbangan antara kemampuan jaringan untuk mengenali pola yang digunakan selama pelatihan serta kemampuan jaringan untuk memberikan respons yang benar terhadap pola masukan yang serupa (tapi tidak sama) dengan pola yang dipakai selama pelatihan. (Siang, 2005). ANN menggunakan sejumlah unit komputasi sederhana yang disebut neuron. yang terhubungkan secara bersama membentuk jaringan node (simpul) yang disebut jaringan syaraf, dimana meniru perilaku sel tunggal otak manusia (Halide dan Ridd 2000). Pengolahan aktual dalam suatu jaringan terjadi dalam simpul pada lapisan tersembunyi dan lapisan output. Lapisan input memberi umpan kepada lapisan tersembunyi kemudian dalam lapisan tersembunyi terjadi proses pembelajaran, sehingga nilai output mendekati nilai target dengan galat yang minimal (Habra 2005).

Fungsi aktivasi. Fungsi aktivasi dilakukan untuk mengubah nilai masukan dalam satu range data tertentu sehingga semua polanya memiliki jarak yang sama.

Proses pelatihan (training). Pada tahap training dilakukan beberapa kali percobaan untuk mendapatkan parameter hidden layer dan learning rate yang baik. Training merupakan proses pelatihan dari sistem jaringan syaraf yang mengatur nilai input serta bagaimana pemetaannya pada output sampai diperoleh model yang sesuai.

Proses pengujian (testing). Proses pengujian dilakukan untuk menguji prestasi pelatihan dan sebagai pendukung jaringan terpilih sebagai jaringan yang tepat untuk model peramalan. Tahap testing digunakan untuk menguji validasi data yang telah dilakukan pada proses training dengan memasukkan data baru yang belum pernah dilatih sebelumnya untuk mengetahui nilai error yang dihasilkan.
Proses peramalan (forecasting). Proses peramalan dilakukan dengan menggunakan jaringan terpilih.

\section{HASIL DAN PEMBAHASAN}

\section{Analisis Spektral}

Hasil analisis data curah hujan menunjukkan signal yang dibentuk oleh data curah hujan selama kurun waktu 37 tahun memiliki tipe data periodisasi yang siklusnya cenderung berulang pada waktu tertentu (Gambar 2).

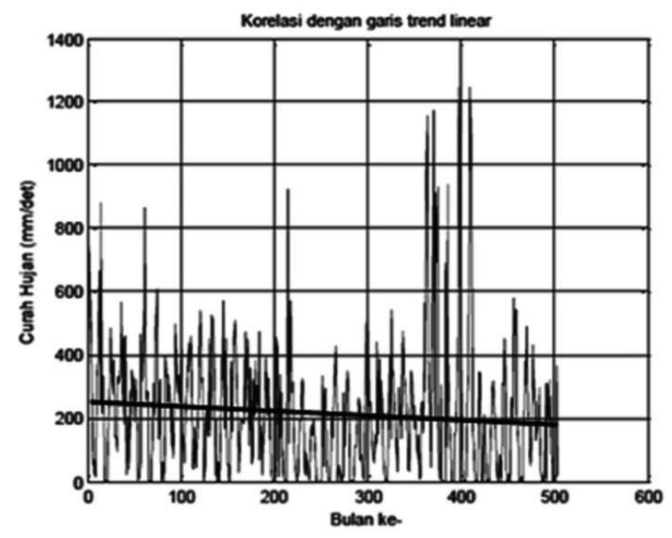

Gambar 2. Periodisasi data curah hujan runtun waktu (1975-2012)

Selanjutnya FFT akan menghasilkan bagian real dan imaginer dari signal tersebut. (Gambar 2), yang merupakan bentuk koefisien Fourier didalam bidang yang komplek yang dihasilkan oleh signal FFT. Dimana sumbu Y menyatakan bagian yang imaginer sedangkan sumbu $\mathrm{X}$ menunjukkan bagian yang real. Besarnya magnitude dari hasil FFT disebut Power. Selanjutnya power ini di plot dengan frekuensi dan hasilnya disebut Peridiogram. Untuk melihat sebaran data curah hujan selama 37 tahun (1975-2012) dilakukan plotting data dengan hasil seperti Gambar 3. di bawah ini :

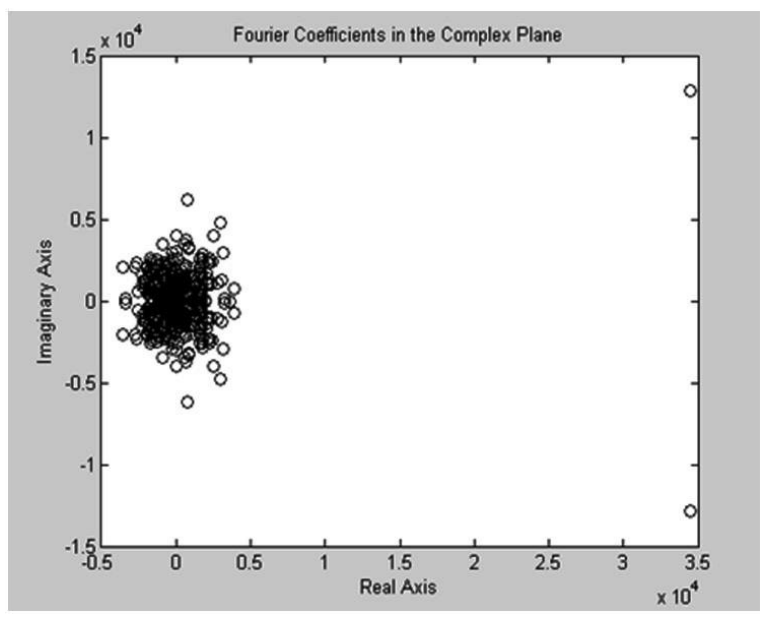

Gambar 3. Plot data curah hujan (1975-2012) 
Hasil plotting data menunjukkan bahwa data curah hujan wilayah pada lokasi penelitian mempunyai sebaran yang cukup merata dimana hanya sedikit data yang berada diluar garis data lainnya (pencilan). Hasil analisis ini membuktikan bahwa data yang digunakan baik untuk dijadikan data model.

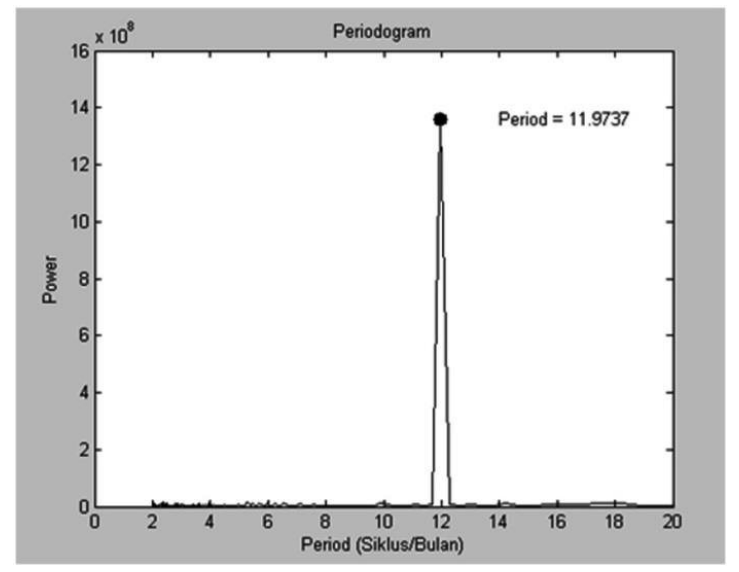

Gambar 4. Periodogram data curah hujan (1975-2012)

Hasil analisis periodogram curah hujan menunjukkan periodisitas curah hujan yang memiliki nilai Kekuatan Kerapatan Spektral (KKS) yang tertinggi yaitu 11,97 atau dapat dibulatkan menjadi 12 bulan/siklus (Gambar 4.). Hal ini menunjukkan bahwa karateristrik perubahan curah hujan, cenderung akan mengalami kenaikan atau penurunan curah hujan setiap \pm 12 bulan sekali. Periode dengan KKS tertinggi menunjukkan periode data curah hujan yang paling sering berulang. Analisis periodogram curah hujan menunjukkan besarnya frekuensi data untuk masing-masing siklus fase dan frekuensinya. Hasil analisis periodogram menunjukkan bahwa curah hujan di wilayah selatan Jatiluhur dipengaruhi angin monsun yang menyebabkan pola curah hujan di wilayah tersebut memiliki satu puncak curah hujan selama setahun.

\section{Prediksi Curah Hujan}

Prediksi curah hujan menggunakan metode Artificial Neural Network (ANN) Backpropagation memperoleh nilai terbaik arsitektur jaringan adalah 1-20-1 yaitu 1 input layer berisi data curah hujan 20 hidden layer, dan 1 output berisi data curah hujan hasil prediksi dengan nilai MSE 0,001. Performa pengujian/validasi data dapat dikenali dengan baik sesuai hasil pengujian $\mathrm{MSE}=0,0129$. Tahap testing menggunakan metode feedforward (langkah maju) dengan arsitektur 1-20-1, learning rate $(\alpha)=0,9$. Tahap testing tersebut menghasilkan nilai kuadrat error sebesar 0,0116. Model yang telah didapatkan digunakan untuk memprediksi curah hujan. Hasil prediksi (Gambar 5) menunjukkan error yang cukup baik yaitu $\mathrm{MSE}=0,07$.

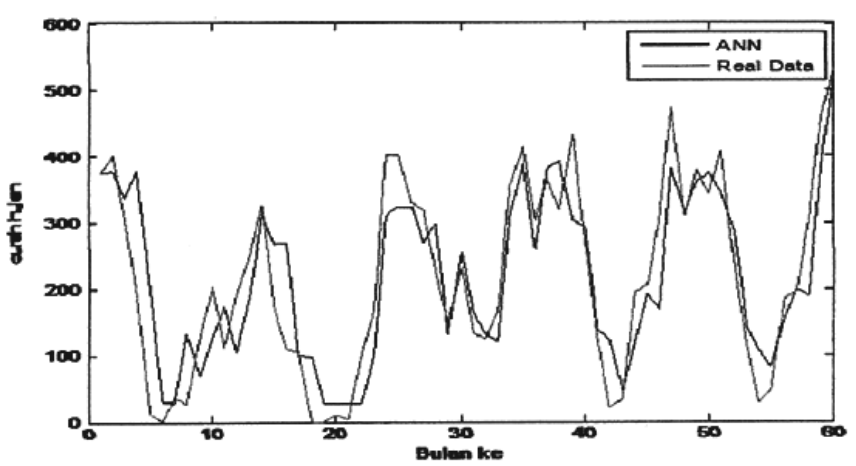

Gambar 5. Hasil predisi ANN dibandingkan dengan data sebenarnya

Setelah melakukan pemodelan, maka model yang telah didapatkan digunakan untuk memprediksi bagaimana keadaan hingga 37 tahun mendatang menggunakan input data yang telah dimiliki dan kemudian hasilnya dibandingkan dengan real data atau data yang sebenarnya (Gambar 6).

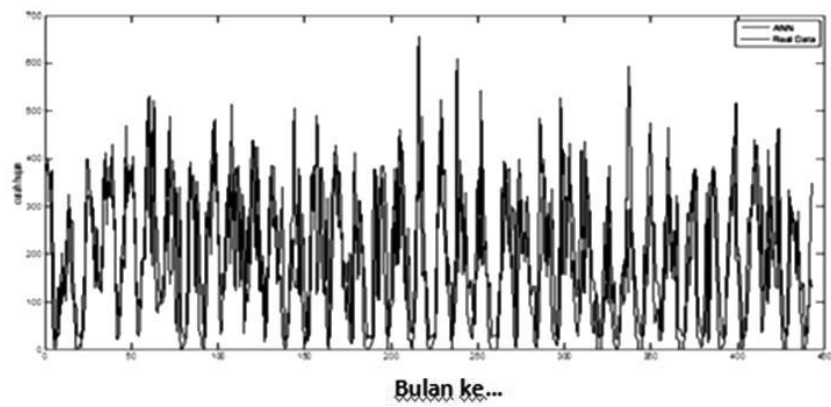

Gambar 6. Validasi Model ANN dengan data sebenarnya

Garis yang berwarna abu-abu adalah nilai curah hujan yang sebenarnya, sedangkan garis yang warna hitam adalah nilai curah hujan yang dihitung menggunakan model ANN. Langkah berikutnya yaitu menghitung nilai error (perbedaan antara nilai perhitungan model ANN dengan data sebenarnya). Hasilnya seperti tampak pada Gambar 7.

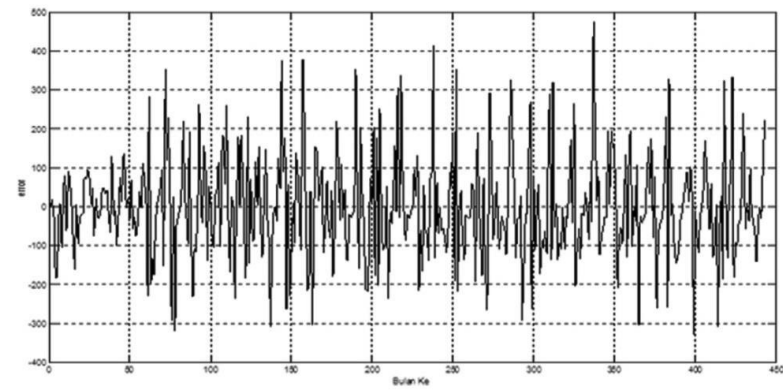

Gambar 7. Data error validasi model ANN dengan data sebenarnya

Data error tersebut kemudian dianalisis spektral menggunakan analisis FFT untuk mengetahui nilai/informasi 
yang bisa diekstrak terkait dengan perubahan siklus atau nilai ekstrim yang terdapat pada data error hasil perbandingan antara ANN dan data sebenarnya. Dalam analisis FFT, salah satu parameter yang harus diperhatikan adalah terkait dengan nilai parameter "nyquist" yaitu parameter untuk pencuplikan data sampling analisis FFT-nya. Sampling yang digunakan adalah 12 bulan/12 data per sample hal ini disebabkan karena hasil analisis FFT pada siklus curah hujan menunjukkan bahwa karakteristrik curah hujan siklus nya adalah tiap 12 bulan/siklus. Data ini kemudian digunakan untuk menjadi jumlah sampling data pada Fourier analysis terhadap nilai error dari model ANN yang digunakan untuk menganalisis pola perubahan iklim (data ekstrim berdasarkan error/ perbedaan siklus normal berbasis model ANN dengan data sebenarnya). Hasil yang diperoleh seperti pada Gambar 8.

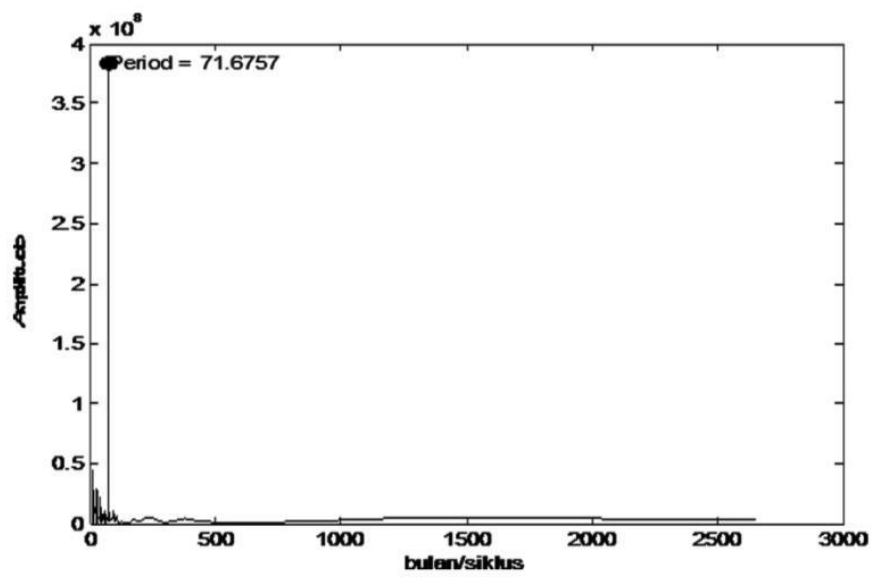

Gambar 8. Periodogram waktu terjadinya perubahan siklus curah hujan berdasarkan data model ANN dan data sebenarnya

Data tersebut menunjukkan bahwa terjadi nilai perubahan siklus ekstrim pada data error antara model ANN dengan data sebenarnya pada bulan ke 71,68 atau sekitar 5-6 tahun. Hal ini menunjukkan bahwa ada suatu gejala perubahan data ekstrim terjadi pada tahun ke 5-6. Sebagai keterangan sumbu x dari grafik hasil analisis FFT adalah "data bulan per siklus" sedangkan sumbu y adalah power/amplitude datanya. Hasil ini sejalan dengan beberapa penelitian terdahulu yang menggunakan FFT untuk analisis spektral antara lain Syaifullah (2010) menggunakan metode spektral pada data curah hujan wilayah DAS Citarum dan hasil analisis menunjukkan bahwa curah hujan bulanan selama 19 tahun di DAS Citarum mempunyai periodisitas kurang kuat 32 bulan (sekitar 3 tahun) sedangkan pada suhu muka laut selain perulangan tahunan, juga mengalami perulangan musiman dan perulangan beberapa tahunan meskipun tidak tampak jelas. Azteria dkk. (2008) menggunakan metode spektral untuk analisis pola curah hujan di Koto tabang, Padang panjang dan Sicincin menunjukkan ketiga wilayah tersebut memiliki pola yang sama dengan pola Monsun yaitu berosilasi sekitar 12 bulan dan hasil ini menunjukkan perbedaan dengan pola di kota Bandung dimana selain siklus 12 bulanan juga terdapat siklus 6 bulanan yang kuat. Sagita dkk. (2013) melakukan analisa spektral data curah hujan di Sulawesi Utara dan telah menghasilkan peta distribusi spasial periodisitas spektral wilayah Sulawesi Utara yang terklasifikasikan menjadi dua tipe periodisitas curah hujan yang memiliki kekuatan kerapatan spektral tertinggi dengan periode 36 dasarian (satu tahun) dan lima tipe periodisitas curah hujan yang memiliki kekuatan kerapatan spektral tertinggi ke dua dengan periode 3-11 dasarian, periode 18 dasarian, periode 36 dasarian, periode 60-110 dasarian dan periode 359 dasarian.

\section{KESIMPULAN}

Hasil analisis data curah hujan menggunakan metode Fast Fourier Transform (FFT) anatra lain periodisitas curah hujan memiliki nilai Kekuatan Kerapatan Spektral (KKS) tertinggi 11,97 atau dapat dibulatkan menjadi 12 bulan/siklus, artinya karateristrik curah hujan, cenderung akan mengalami kenaikan atau penurunan curah hujan setiap \pm 12 bulan sekali (siklus hidrologi). Curah hujan di wilayah selatan Jatiluhur dipengaruhi angin monsun yang menyebabkan pola curah hujan di wilayah tersebut memiliki satu puncak curah hujan selama setahun. Prediksi curah hujan menggunakan metode Artificial Neural Network (ANN) Backpropagation memperoleh nilai terbaik arsitektur jaringan adalah 1-201 Hasil prediksi menunjukkan error yang cukup baik yaitu $\mathrm{MSE}=0.07$. Silus perubahan curah hujan terjadi dalam kurun waktu 71,68 bulan atau sekitar 5-6 tahun.

\section{DAFTAR PUSTAKA}

Aldrian, E. dan Susanto. R.D. (2003). Identification of three dominant rainfall regions within Indonesia and their relationship to sea surface temperature. International Journal of Climatology 23: 1435-1452.

Anonymous (2013). Siklus madden Julian oscillation. http://www.meted.ucar.edutropical textbook2nd editionmediagraphicsMJO_cycle_1971_translated_to WH2004.jpg. [25 Januari 2013].

Azteria. V., Effendy, S. dan Hermawan, E. (2008). Pemanfaatan data equatorial atmosfer radar (EAR) dalam mengkaji terjadinya Monsun di kawasan barat Indonesia. Jurnal Agromet Indonesia 22(2): 160-173.

Boer, R., Buono, A., Sumaryanto, E., Surmaini, A., Rakhman, W., Estiningtyas, K., Kartikasari, dan Fitriyani. (2009). Agriculture Sector. Technical Report on Vulnerability 
and Adaptation Assessment to Climate Change for Indonesia's Second National Communication. Ministry of Environment and United Nations Development Programme, Jakarta.

Habra, A. (2005). Neural networks, an introduction. http://www.tek271.com/articles/ neuralNet/ IntoToNeuralNets.html. [5 Oktober 2005].

Halide, H. dan Ridd, P. (2000). Modeling inter-annual variation of local rainfall data using a fuzzy logic technique. International Forum on Climate Prediction, Agriculture and Development, James Cook Univ. 26-28 April 2000, IRI, Australia. 2000.

Hermawan, E. (2010), Pengelompokan pola curah hujan yang terjadi di beberapa kawasan pulau Sumatera berbasis hasil analisis teknik spectral. Jurnal Badan Meteorologi dan Geofisika 11(11): 75-78.

Hermawan. E, (2003). The characteristics of Indian ocean dipole mode preliminary study of the monsoon variability in the western part of Indonesian region. Jurnal Sains Dirgantara 1(1): 65-75 Desember 2003.

Las, I., Rontuwu, E., Syahbuddin, H., Subagiyono, K., Unadi, A., Amien, I., Hariyanti, K.S., Nugroho, M.W.T., Hamdani, A., Surmaini, E., Shofiyati, R., Ramadhani, F., Adi, S.H., Nasrullah, dan Parmudia, A. (2007-2010). Atlas Kalender Tanam Jawa-SumateraSulawesi, Kalimantan-Bali, Nusa Tenggara, Maluku, Papua. Badan Penelitian dan Pengembangan Pertanian, Jakarta.

Makridakis, S., Whellwright, S.C. dan Mc Gee, V.E. (2003). Metode dan Aplikasi Peramalan. Binarupa Aksara Publisher, Tangerang.
McBride (2002). Kapan Hujan Turun? Dampak Osilasi Selatan dan El Nino di Indonesia. Department of Primary Industries, Queensland.

Mulyana (2004). Analisis Spektral untuk Menelaah Periodesitas Tersembunyi dari Data Deret Waktu. Statistika Fakultas Matematika dan Ilmu Pengetahuan Alam. Universitas Padjadjaran, Bandung.

Sagita, N., As'ari, dan Wandayantolis. (2013). Analisis spektral data curah hujan di Sulawesi Utara. Jurnal Fakultas Matematika dan Ilmu Pengetahuan Alam 2(2): 133-139.

Sathiyamurthy, V. dan Mohanakumar, K. (2002). Characteristics of tropical biennial oscillation and its possible association with stratospheric QBO. Geophysical Research Letters 7: 669-672.

Siang, J.J. (2005). Jaringan Saraf Tiruan dan Pemrogramannya Menggunakan MATLAB. Penerbit ANDI, Yogyakarta.

Sutarto, A., Jasis, W.W.G., Subroto, Siswanto, M. dan Sudiyanto, E. (2001). Sistem Peramalan dan Pengendalian OPT dalam Mendukung Sistem Produksi Padi Berkelanjutan. Dalam Implementasi Kebijakan Strategi untuk Meningkatkan Produksi Agribisnis dan Lingkungan. Pusat Penelitian dan Pengembangan Tanaman Pangan.

Syaifullah, D. (2010). Analisis suhu muka laut selatan Jawa dan pengaruhnya terhadap curah hujan DAS Citarum. Jurnal Sains dan Teknologi Modifikasi Cuaca 11(2): 11-19. 